\title{
ETHICALITY OF CONSUMERIST RELATIONS. TISCHNER'S AND BAUMAN'S LOOK AT THE EXISTENCE OF CONTEMPORARY MAN
}

\author{
Izabela MARSZAŁEK-KOTZUR \\ Politechnika Śląska Wydział Organizacji i Zarządzania, Katedra Stosowanych Nauk Społecznych; \\ izabela.marszalek-kotzur@polsl.pl, ORCID: 0000-0002-8426-0170
}

Purpose: The purpose of the research is to determine the condition of a contemporary man immersed in the realities of consumerism based on the texts of Sigmund Bauman and Józef Tischner.

Design/methodology/approach: The objective has been achieved by using critical textual analysis and the phenomenological method, together with hermeneutic interpretation both in relation to the phenomena of the surrounding world, as well as the texts of Sigismund Bauman and Józef Tischner.

Findings: During the course of work, a convergence of the views of the above thinkers was found.

Research limitations/implications: The research process has been limited to the texts of Bauman and Tischner.

Social implications: The article can be an inspiration to change the way people live in the society and restore forgotten values.

Originality/value: This article is addressed both to the human being in society and to those responsible for creating human behavior.

Keywords: relations, consumption, ethics, freedom, responsibility.

Category of the paper: viewpoint.

\section{Introduction}

Technological advances and rapid economic development have increased people's wealth. The possibility of purchasing more and more goods and using a number of services has today become a criterion determining the social status of a man. Increasingly intersecting economic, consumer and private spheres have created a specific culture called consumer culture. The consequence is not only over-exploiting the environment, but also the progressive objectification of human relationships, and the social exclusion of people who cannot or 
consciously do not want to identify with it. One of the "diagnosticians" of the socio-political reality of the early 21 st century is Zygmunt Bauman, who refers to it using the term "liquid modernity". This fluidity involves "melting everything fixed", that is, the gradual release of the economy from traditional, cultural and interpersonal bonds. Living in that reality entailed the need for a man to adapt to the new rules of social life. The result of this process is the emergence of a society known as a "consumer society", characterised by the tendency to tie-up human relationships based on market principles. Bauman's in-depth analysis of the structures of this society provided an insight into the state of the modern man. In the field of understanding the complex interdependence of human relationships, it is impossible to ignore Józef Tischner's ethical considerations. This paper is an encouragement to reflect on the condition of modern man immersed in consumerist realities and to find common or complementary threads in the views of Bauman and Tischner, which could inspire reflection on the attempt to change the way of human life and restore forgotten values that are important to human existence.

\section{Consumer society}

The concept of consumer society, although it operates in general use, has not yet been given a clear and unambiguous definition. It is generally accepted that this is a modern society which, as a result of the improvement in quality of life, treats consumption as an overriding priority, assigning to it other areas of life, such as morality, customs, politics. According to Zygmunt Bauman, consumer society is "a set of living conditions in which the probability of adopting consumerist culture and acting in most cases according to its orders is high. In other words, 'consumer society' is a society that promotes the choice of a consumerist lifestyle and life strategies, encourages or coerces people to it, plunging all its cultural alternatives into dismay" (Bauman, 2009, pp. 61-62). Its main feature is to bring all elements of reality to the level of consumer goods, that is, merchandise. The consumer must live in the belief that the recipe for solving any problems that life is facing will always be found on the market, it is enough to pay the right amount of money (Marszałek-Kotzur, 2019a).

Bauman distinguishes the concept of consumption, defining the act of consuming, which is a characteristic of a single individual, from the concept of consumerism, understood as an attribute of society as a whole. The two concepts are closely interlocked, as the consumer society is formed as the result of the transformation of individuals with ever greater and stronger desires into "collective consumers" (Marszałek-Kotzur, 2019a).

In the lives of previous generations, consumption served as a meeting of the human needs of everyday life. But, Bauman says, due to the collapse of ethical norms and the new phenomenon of plasticity of "needs", it got released from the chains of functionality and changed the meaning of the term "need". Traditional psychology defines "need" as a state of 
tension that discharges and fades away. However, today's need is expected to constantly build and sustain this tension. As Bauman notes, "consumer society preaches inability to satisfy the needs and its progress is measured in terms of the ever-increasing desire" (Bauman, 2007, pp. 212). Tischner calls such a condition uncritical consumption, and when: "'benefit' passes into the delight of 'use' for the very use; we don't ask about the goal, we keep playing with the means to reach this goal" (Tischner, 2005, p. 277). Today's needs are the desires awakened by so-called occasions. Ads inform potential consumers about new products they could not have desired before, without knowing their existence (Bauman, 2004; 2007).

Tischner calls the current world a marketplace that offers us countless "things, objects, ideas, even people" (Tischner, 2008, p. 63). In this market, some people promise happiness, while others threaten us with an inevitable misfortune. Markets attract our attention, forcing us to constantly look at the goods on display and listen to what is, as Tischner writes, "shouted". According to Tischner "The marketplace does not allow you to cross its space, it still forces you to return, to watch the same things many times. Above all, however, the marketplace imposes its own language on us. Who has stayed at the market for some time, cannot speak the language different from the language of the market. Nor can such a person think differently they become part of the marketplace" (Tischner, 2008, p. 63). The marketplace, or as Bauman would put it - the market, systematically drags us into its space, brutally and noisily seizing us and not allowing us to escape from its influence.

Bauman believes that the most common experience today, intensive and absorbing, in which the consumer participates, is the experience of life as a series of consumer choices, made in response to attractions, increasingly shaped, perceived and "justified" according to the imposed pattern (Bauman, 2007). In the social space, this means imposing patterns of behaviour and limiting the ability of individuals to make choices.

The logic of a consumer-oriented economy adjusted to the requirements of consumerism also includes a shift from having things to being able to get rid of them and throw them away. (Bauman, 2011) Acquired items need to quickly come out of use, you need to quickly part with them without regret, so that you can replace them with products "newer and better" (Bauman, 2009c).

\section{Consumption and human relations}

According to Bauman, in a consumer society, not only material things must be subject to a process of continuous exchange. This also applies to interpersonal relationships, which should also mimic the buyer's relationship with the items purchased. When they begin to disturb, they need to be removed. As Bauman points out, consumer-type relationships are by definition focused on continuing until further notice. Nowadays, long-term investment, both in material 
goods and in the life partner, is not an option. "Pleasure" life is lived as a series of pleasant moments that do not even have to add up, or create anything specific (Bauman, 2007). Long-term commitments and lasting bonds are perceived limiting to human beings and today they are seen to be the antithesis of a happy life (Bauman, 2007). Entering a lifelong contract fills people with fear because, as Bauman points out, it's like signing a blank cheque. (Bauman, 2009c). There are problems, difficulties, unforeseen situations out of which there may not be a way to escape. Therefore, it is better to start a new relationship without over-involvement. It will last as long as it brings mutual satisfaction (Marszałek, 2019a).

Bauman points out that the relationship of the consumer type concerns not only individual relationships, but entire human communities (Bauman, 2008; 2012b). There has been a disintegration of traditional forms of community and great formal social structures, and in their place there came a new kind of social relations organization, like virtual communities, online communities. They are characterized by their intensity but are both flexible and temporary. They are based on the interest in specific resources of the individual, the individual's access to information and contacts, which allows to achieve their own goals (Marszałek-Kotzur, 2019b). The ease of breaking and banning them extracts a new variation of interpersonal relationships. Face-to-face direct contacts are subordinate to electronically mediated.

Consumerism has also entered the space of human work, destroying relationships between co-workers. Employees are subject to merciless pressure to be creative. The work has been instrumentalised and its value is assessed according to the standards of consumer experience (Bauman. 2007). Tischner states that there has been a new concept in the area of work, the socalled "demand". The introduction of the demand criterion in the working space led, according to Tischner, to a profound social upheaval. Unprofitable workplaces have been closed, many jobs have been lost, resulting in unemployment and the exclusion of entire crowds (Tischner. 2005). Tischner also points to the change that has taken place in the very concept of work. Today, every activity that creates utility values that someone is willing to pay for on the market (Tischner. 2005) is defined as work. The market, with its competitiveness principle and demand criterion, can foster the development of many forms of work, but on the other hand it can lead to their destruction. That's why Tischner, when making a diagnosis of the modern state of human work, states that: "The nature of work is decided by the market. The market breeds jobs but the market can also kill them" (Tischner. 2005, p. 275). According to Tischner, the market has also an impact on modern axiology: "after an era of struggle for absolute values, the time has come for utilitarian values" (Tischner. 2005, p. 275), the usefulness of which is determined by the free market.

According to Bauman, the consumer market has also influenced the family relationships. It offers us its paid services in order to make up for the time spent making money. Because there is not enough time to talk together, show interest to our loved ones, we buy expensive gifts. The more we pay, the better we feel, having the sense of rewarding our absence (Bauman, 2009c). We have learned to compensate for our time with material gifts. In this way, shopping 
becomes something like a moral deed (Bauman, 2012c). Consumer markets help us silence moral scrupulous, which is an clear signal of the dangers to human ties. They could have been subjected to deeper reflection had they not been drowned out by market-supplied products (Bauman, 2009a; 2012c)

In the consumer society, Bauman notes, the world should be orderly and clean. When the measure of purity becomes the ability to participate in, as Bauman writes, consumer fun, people who do not participate in it are a problem. They are called impurity. It's about people suffering from deprivation, homeless, begging. They should be removed because they are unnecessary. Hence, against such "consumers with a glitch" (Bauman, 2000, p. 29), guards are hired in shopping malls, or the cameras are installed. Similarly, residents of luxury settlements follow, treating their houses as fortresses to which so-called strangers do not have access. Strangers are tolerated as much as they are useful. They can sometimes be providers of pleasure when the customer pays, requires, evaluates and decides at which point the contact will end (Bauman, 2000). People who hide from others are called by Tischner "people from hiding places". In their hideout, the man protects himself from the world and from others. To all who approach this hideout, $\mathrm{He}$ is guided by the suspicion that all who approach this hideout are approaching it only to rob and destroy it. In order to keep the other man safely away from the wall of the hideout, you need to conduct a kind of struggle to capture him (Tischner, 2002). According to Tischner, people from hiding places suffer from a disease of hope. The future does not promise such a man anything interesting, and the memory of the past gives insults to failure. In the hideout you can safely survive (Marszałek, 2014).

A similar condition experienced by people from hideouts is melancholy, which seems to be the share of a large number of people today. Tischner's description of melancholy shows the position of a man who succumbs to moods, regrets a lost opportunity, is overwhelmed by a sense of defeat (Tischner, 2008). Man cannot find himself in the world, because he seems to find himself in the wrong place and at the wrong time. Melancholy, as Tischner states, is constantly looking for entertainment to escape from one another, from one's love, from despair, from sacrifice, from some choice. There are so many possibilities for the man to choose that he is not able to pick any of them. As Tischner writes, "Because the man is allowed too much, he doesn't do anything. He stands suspended between possibilities, unable to take a step further" (Tischner, 2008, p. 60). Man is trapped by grief and powerlessness, unseen desire for self-assertiveness and self-esteem, adds Bauman (Bauman, 2007). 


\section{Ethical imagination in the space of freedom}

By producing a countless number of different products, extending the range of possibilities for a man, we disrupt the world order and push further the boundaries in the search for something (Delsol, 2002). Bauman agrees with Hannah Arendt that today's human autonomy has evolved into a tyranny of opportunity (Bauman, 2000). According to Tischner, the contradiction between what is possible for man and what should become the limit of opportunity shows us in a new light the need to use the acquis of ethics, because the role of ethics is not only to set limits on increasing possibilities of technology, but also to show the differences between what is necessary, what is essential and what is crucial (Tischner, 2000).

The effects of human action on a global scale are so radical today that we can hardly predict the results. They demand many answers to ethical issues. Unfortunately, the increase in awareness of human moral responsibility does not go hand in hand with technological development and increased consumption, pessimistically states Bauman (Bauman, 2000). Great ethical problems, such as human rights, justice, the coordination of the interests of the individual and the common weal have not lost their relevance, it is crucial, however, to deal with them in a new way (Bauman, 2012a). The thought of Tischner seems to be similar, as he tries again to reach the sources of human ethical sensitivity (Tischner, 2002).

Both Bauman and Tischner are not in favour of constructing new and complex ethical standards. Both are convinced that the mankind must confront the consequences of their own actions by themselves. According to Tischner, ethics can only be developed by awakening creative imagination and intuition, which dictate what to do at any given moment. Moral principles cannot be memorized or disseminated (Tischner, 2002). The result of imposing universal norms, as Bauman notes, is merely silencing moral impulses and directing moral qualifications to imposed actions (Bauman, 2012a). Tischner, when studying ethical issues in terms of history, believes that “(...) true moral progress made throughout history is made not by those who wash their hands of problems, but by those who are not afraid to accept responsibility and guilt" (Tischner, 2008, p. 39).

The concept of responsibility in terms of ethics is crucial (Kuzior, 2006). As Tischner argues, "the truth of man is expressed in the purest way in the sense of responsibility. This is it that distinguishes and binds man to the world, it testifies to his freedom and towards values, and in it expresses the fullest of man's special trust in his own existence (...)" (Tischner, 2002, pp. 43-44). It can be said that a sense of responsibility is what builds humanity (Bauman, $2009 b)$. However, a precondition for responsibility to develop is freedom. The consequence of freedom are the decisions that change the course of human life. Freedom is not only a lack of external obstacles and coercion, but above all it is a dynamic factor that shapes the world and the man. Freedom releases hope for the fulfillment of the deepest desires and highest aspirations of the man (Zuziak, 2002). 
According to Tischner, freedom is a dramatic category. It appears between people who are free from each other (Tischner, 2001). The presence of the other in that space of relations requires recognition in terms of their dignity and freedom. The idea is to find yourself and your place with others and others in a meaningful space of the world (Tischner, 2001). Only a free man can make a responsible choice between good and evil. But what is the essence of the choice? To choose means to assimilate something, make it "mine", make it "part of yourself", says Tischner (Tischner, 2001, p. 305).

Freedom is a unique ethical value as its realisation determines realization of all other personal values. You cannot improve yourself without freely accepting the proposed values (Tischner, 2000). As Tischner points out, thanks to freedom, a man can rise above his small world and look at himself from the outside. By comparing the inner and outer image of himself, the man can get closer to the truth about himself and about the world (Tischner, 2008).

The realization of values is conditioned not only by human freedom, but requires effort of thinking. Tischner believes that thinking is a kind of spiritual force by which man frees himself from illusions, illusions of apparent knowledge, and false certainty. According to Tischner, thinking "clears the dustbin that everyday life makes of our heads" (Tischner, 2008, p. 11). The lost and lonely man sees the world in fragments, is tossed by someone's decisions, exposed to an excess of objects and information, succumbs to illusions and delusions that are the result of human finiteness, experienced on the level of human cognition. The incomplete knowledge in this field promotes the emergence of various appearances. In the consumerist world, man was deprived of the spiritual dimension and became a follower of simple social, physical and economic forces (Giddens, 2010). Trying to think allows the man, at least to some extent, to sort out the chaos that surrounds them. Thinking, however, involves risks, Tischner warns. People attach themselves to their own illusions. It is safer for them to perpetuate illusions than to disperse them.

A man who has decided to undertake the risk of freeing himself from illusion and false selfconfidence enters the deep self and is prepared for the call of goodness, says Tischner (Tischner, 2008). As Tischner writes, thinking allows you to hear the voice of good penetrating through the noises of the world to summon man to something absolute (Tischner, 1990). For Tischner, The Good is the axiom of human drama. Tischner, is convinced that good demands existence. How do we know it? Tischner thinks we know this from our own experience. We want the good, not bad. We have a hunch that in the present world there is a lack of good that should exist. So our intuition tells us that the source of man's experience is good. Even when man does evil, he really wants good. How can we understand good? We can try penetrating into the various dramatic threads it establishes between people. At the bottom of all the threads lies one thing, says Tischner, the seed of good awakened in man by goodness (Tischner, 1990). 


\section{Conclusion}

Living in a world where the logic of consumption dominates, we actually move in the space of influence of various illusions and delusions that appeal to all our senses and try to take over our power of judgement. We are enslaved by the constant anticipation of new trends that are coming in various fields: in automotive, in fashion, in nutrition, in ways of behavior, in leisure, and many more. Without a shadow of doubt we accept everything that is imposed on us, we no longer even wonder by whom. Many of us do not even realize that, in fact, day after day, we allow ourselves to take away our freedom and independence. The enslavement we experience does not allow us to decide for ourselves. Its consequence is a sense of insecurity, uncertainty and anxiety, melancholy, and above all, the changes taking place on the horizon of interpersonal relationships. Bonds with another person in the social sphere, at work, in the family, in partnerships, in social relationships are broken or disturbed. There is a systematic objectification of another person, who becomes, on the one hand, a threat and, on the other hand, a tool for satisfying our daily desires. The distorted experience of another person blunts our sensitivity to the world of ethical values.

Consumption has become a self-perpetuating machine that I think can no longer be stopped. However, in this situation, paradoxically, we are increasingly dependent on each other and both our actions and omissions have an impact on the fate of others. For this reason, as Bauman notes, "from an ethical point of view, we are all responsible for ourselves" (Bauman, 2007, p. 23). And because the world was "built by a man", so it can be rebuilt by the man as well. So the modern reality for Bauman is an invitation to be creative and to let our goodwill speak, through the effort of thinking, which can only take place in the space of human freedom, Tischner would say.

Both freedom and responsibility for Bauman and Tischner play a key role in human life. Freedom gives the man an opportunity for authenticity, allows us to participate in a world of values, and responsibility creates a sense of commitment and opens the door to the realization of good. The transition from incarceration to freedom entails a kind of transformation of experience. The conditions characteristic of enslavement disappear: anxiety, melancholy, sadness, hopelessness and despair. There is joy, certainty, hope and a sense of dignity. Freedom means that the man "can" and not "have to" (Tischner, 2001).

The above considerations do not claim the exhaustion of the issue raised. Only some of the selected questions from the texts of Sigismund Bauman and Józef Tischner concerning the ethical and existential problems of modern man have been reflected. They are intended to demonstrate in a sketchy way that the man, though at risk, is not in a completely lost position and, if they wish, they can change a lot by rereading the call to realize fundamental human values. The ethical and existential problems of modern man demand, especially today, re-examination and diagnosis. The Article may therefore provide a starting point for further research in this area. 


\section{References}

1. Bauman, Z. (2007). Społeczeństwo w stanie oblężenia. Warszawa: Wydawnictwo Sic!

2. Bauman, Z. (2000). Ponowoczesność jako źródło cierpień. Warszawa: Wydawnictwo Sic!

3. Bauman, Z. (2008). Wspólnota. W poszukiwaniu bezpieczeństwa w niepewnym świecie. Kraków: Wydawnictwo Literackie.

4. Bauman, Z. (2009a). Konsumowanie życia. Kraków: Wydawnictwo Uniwersytetu Jagiellońskiego.

5. Bauman, Z. (2009b). Nowoczesność i zagłada. Warszawa: Wydawnictwo Literackie.

6. Bauman, Z. (2009c). Sztuka Życia. Kraków: Wydawnictwo Literckie.

7. Bauman, Z. (2011). Kultura w ptynnej mnowoczesności. Warszawa: Drukarnia Perfekt.

8. Bauman, Z. (2012a). Etyka ponowoczesna. Warszawa: Wydawnictwa Aletheia.

9. Bauman, Z. (2012b). Kultura jako praxis. Warszawa: PWN.

10. Bauman, Z. (2012c). Straty uboczne. Nierówności społeczne w epoce globalizacji. Kraków: Wydawnictwo Uniwersytetu Jagiellońskiego.

11. Bauman, Z., May, T. (2004). Socjologia, Poznań: Zysk i S-ka Wydawnictwo.

12. Delsol, Ch. (2002). Przekraczanie, profanowanie, czyli granice jako problem ponowoczesności. In: W. Zuziak (ed.), Pytając o człowieka. Myśl filozoficzna Józefa Tischnera (pp. 61-64). Kraków: Wydawnictwo Znak.

13. Giddens, A. (2010). Nowoczesność i tożsamość. “Ja” i społeczeństwo w epoce późnej nowoczesności. Warszawa: PWN.

14. Kuzior, A. (2006). Człowiek jako racjonalny podmiot działań w świetle założeń koncepcji zrównoważonego rozwoju. Problemy Ekorozwoju, $n r$ 1(2). Polska Akademia Nauk, pp. 67-72.

15. Marszałek, I. (2014). Józef Tischner I filozoficzne koncepcje zła. Czy zło jest w nas, czy między nami? Kraków: Wydawnictwo WAM.

16. Marszałek-Kotzur, I. (2019b). Społeczeństwo konsumpcyjne. Cechy człowieka ponowoczesnego w ujęciu Zygmunta Baumana. In: L. Karczewski, H.A. Kretek (eds.), Humanistyczne i spoleczne aspekty biznesu i zarzadzania (pp. 59-67). Opole: Oficyna Wydawnicza Politechniki Opolskiej.

17. Marszałek-Kotzur, I. (2019a). Tischnerian land husbandry Ethical aspects of management of the environment. Scientific Papers of Silesian University of Technology Organization and Management Series, no. 140. Gliwice, pp. 197-205.

18. Tischner, J. (2001). Spór o istnienie człowieka. Kraków: Wydawnictwo Znak.

19. Tischner, J. (1990). Filozofia dramatu. Paryż.

20. Tischner, J. (2000). Świat ludzkiej nadziei. Kraków: Wydawnictwo Znak.

21. Tischner, J. (2002). Myślenie według wartości. Kraków: Wydawnictwo Znak. 
22. Tischner, J. (2005). Etyka solidarności oraz Homo Sovieticus. Kraków: Wydawnictwo Znak.

23. Tischner, J. (2008). Wędrówki w krainę filozofów. Kraków: Wydawnictwo Znak.

24. Zuziak, W. (2002). W poszukiwaniu wolności - między J. Nabertem i J. Tischnerem. In: W. Zuziak (ed.), Pytając o człowieka. Myśl filozoficzna Józefa Tischnera (pp. 43-59). Kraków: Wydawnictwo Znak. 